\title{
Clinical endometritis in an Argentinean herd of dairy cows: Risk factors and reproductive efficiency
}

\author{
M. J. Giuliodori, ${ }^{*}$ R. P. Magnasco,† D. Becu-Villalobos,‡ I. M. Lacau-Mengido,‡ C. A. Risco,§ \\ and R. L. de la Sota\# $\|^{1}$ \\ ${ }^{*}$ Cátedra de Fisiología, Facultad de Ciencias Veterinarias-Universidad Nacional de La Plata (FCV-UNLP), La Plata, B1900AVW, Argentina \\ †Estudio Magnasco, Canals, Córdoba, X2650BXC, Argentina \\ łlnstituto de Biología y Medicina Experimental-Consejo Nacional de Investigaciones Científicas y Técnicas (IByME-CONICET), Buenos Aires, \\ C1428ADN, Argentina \\ §Large Animal Clinical Sciences (LACS), College of Veterinary Medicine, University of Florida (CVM-UF), Gainesville 32611 \\ \#Cátedra y Servicio de Reproducción Animal, FCV-UNLP, La Plata, B1900AVW, Argentina \\ ICONICET, Buenos Aires, C1033AAJ, Argentina
}

\section{ABSTRACT}

The objectives of this study were to assess the clinical and metabolic risk factors for clinical endometritis, the likelihood for having a normal vaginal discharge during postpartum, and the effects of endometritis on milk yield, reproductive efficiency, and metabolic status in Holstein cows. The study was conducted in a commercial dairy herd (Cordoba, Argentina) where 303 Holstein cows were enrolled. Cows were body condition scored (1 to 5 ) and tail bled on $-14,7,21,31,41$, and $50 \mathrm{~d}$ relative to parturition. Cows having a vaginal discharge with presence of pus between 21 and $41 \mathrm{~d}$ postpartum (dpp) were diagnosed as having clinical endometritis. Plasma blood samples were analyzed for nonesterified fatty acids (NEFA), $\beta$-hydroxybutyrate (BHBA), and blood urea nitrogen using commercial kits and insulin-like growth factor 1, insulin, and leptin by RIA. Data were analyzed with PROC MIXED, PROC GENMOD, and PROC PHREG of SAS (SAS Institute Inc., Cary, NC). Abnormal calving and puerperal metritis increased the risk for endometritis [adjusted odds ratio $(\mathrm{AOR})=2.21$ for both]. High prepartum NEFA and high postpartum BHBA increased the risk for endometritis (AOR $=1.003$ and 1.001, respectively), whereas high prepartum blood urea nitrogen reduced it $(\mathrm{AOR}=0.853)$. Cut-offs of $456.6 \mu M \mathrm{NEFA}$ and $402.5 \mu M$ BHBA had sensitivities of 0.69 and 0.58 , and specificities of 0.88 and 0.86 , respectively. The likelihood for having normal vaginal discharge increased with time $(\sim 1 \% \times \mathrm{dpp})$ and with normal calving. Cows with endometritis had higher milk yield than normal herdmates $(27.8 \pm 0.9$ vs. $25.7 \pm 0.4 \mathrm{~kg} / \mathrm{d})$, lower risk for pregnancy by $100 \mathrm{dpp}(\mathrm{AOR}=0.10)$, higher nonpregnancy risk by $200 \mathrm{dpp}(\mathrm{AOR}=2.87)$, and higher

Received May 2, 2012.

Accepted September 19, 2012.

${ }^{1}$ Corresponding author: dairydoc $82 @$ gmail.com risk for culling than normal cows $(\mathrm{AOR}=2.28)$. Cows with endometritis had a lower hazard rate $(0.44)$ for pregnancy and had approximately $70 \mathrm{~d}$ longer calvingto-conception intervals. Finally, endometritis had no effect on metabolic hormones. In conclusion, the risk for clinical endometritis increases with abnormal calving and puerperal metritis, as prepartum NEFA and postpartum BHBA concentrations increase. Prepartum NEFA and postpartum BHBA could be useful for the prediction of endometritis. Last, clinical endometritis has detrimental effects on reproductive efficiency, as affected cows take longer to get pregnant and are at higher risk for culling.

Key words: dairy cow, clinical endometritis, risk factor, reproductive efficiency

\section{INTRODUCTION}

Uterine infections, such as metritis and endometritis, are very common in postparturient dairy cows and are highly associated with reproductive losses (Fourichon et al., 2000; LeBlanc et al., 2002; Gilbert et al., 2005; McDougall et al., 2007; Barlund et al., 2008; Runciman et al., 2008; Gautam et al., 2009, 2010; Dubuc et al., 2010a, 2011b). An interesting finding regarding uterine infections is that general consensus exists about their detrimental effects on reproductive performance but no standard definition has been universally accepted (Gilbert et al., 2005; Barlund et al., 2008). Examination of vaginal discharge (VD) is one of the most useful diagnostic procedures, as the presence of pus in the vagina is correlated with the presence of pathogenic bacteria in the uterus (LeBlanc et al., 2002; Williams et al., 2007). Fortunately, case definitions for uterine diseases have recently been proposed (Sheldon et al., 2009). Thus, cows having pus in VD, $21 \mathrm{~d}$ postpartum (dpp) or more, without systemic signs of illness are defined as having clinical endometritis and cows having a high percentage of polymorphonuclear cells 
in uterine cytology samples 21 to $47 \mathrm{dpp}$ are defined as having subclinical endometritis (Sheldon et al., 2009). Among the most widely accepted clinical risk factors for endometritis are calving problems (dystocia, retained placenta, and stillbirth) and metritis (Ghanem et al., 2002; Le Blanc et al., 2002; Dubuc et al., 2010a; Gautam et al., 2010; Potter et al., 2010). Regarding metabolic risk factors for the disease, results have been controversial. Some researchers found an effect of high prepartum NEFA on the risk for endometritis (Könyves et al., 2009; Kaufmann et al., 2010), whereas others do not (Dubuc et al., 2010a). Therefore, no concluding data exist about the effect of negative energy balance on the risk for endometritis. Also, there is a lack of data on the effect of endometritis on metabolic hormones (Burke et al., 2010).

The objectives were to assess (1) the (clinical and metabolic) risk factors for clinical endometritis in Holstein dairy cows; (2) the value, at the individual cow level, of these metabolic indicators as predictors for the risk for endometritis; (3) the evolution of VD during the postpartum period; and finally, (4) the effects of endometritis on reproductive performance, milk yield, and indicators of metabolic status (metabolites and metabolic hormones).

\section{MATERIALS AND METHODS}

\section{Animals and Treatments}

The study was conducted in a commercial dairy herd (32 $49^{\prime} \mathrm{S}, 62^{\circ} 52^{\prime} \mathrm{W}$, Argentina) where autumn-calving Holstein cows $(\mathrm{n}=303)$ were enrolled. Prepartum transition cows that were within $3 \mathrm{wk}$ of expected calving date were maintained on dry lots, fed a diet with low cation-anion difference, and monitored for signs of calving by farm employees trained to assist with parturition. After calving, cows were sent for $3 \mathrm{~d}$ to the fresh herd and kept on a dry lot. At 4 dpp, healthy cows were moved to a lactating herd kept in a dry lot and fed 4 times daily. Diets for both pre- and postpartum transition cows were TMR formulated to meet or exceed the requirements of lactating dairy cows according to guidelines established by the NRC (2001). Lactating dairy cows were milked 3 times/d (0400, 1200, and $2000 \mathrm{~h}$ ). Conventional therapy was used for metritis (Ceftiofur hydrochloride, $2.2 \mathrm{mg} / \mathrm{kg}$ of BW i.m. for 3 consecutive days; Ceobiotic; Tecnofarm SRL, Provincia de Buenos Aires, Argentina) and endometritis (150 $\mu \mathrm{g}$ of PGF analog/cow; Ciclase; Syntex SA, Buenos Aires, Argentina). After a voluntary waiting period of $40 \mathrm{~d}$, healthy cows having normal clear or clear with flecks of pus VD were estrous synchronized and received a timed AI (TAI) 50 dpp. Pregnancy was checked by rectal palpation $35 \mathrm{~d}$ post-TAI. After initial TAI, all cows were detected twice daily for estrus and AI using the a.m./p.m. rule.

\section{Sampling}

At $-14,5$ to $7,21,31,41$, and 50 dpp cows were body condition scored (5-point scale; Edmonson et al., 1989; Ferguson et al., 1994) and blood sampled from tail vessels between 1600 to $1800 \mathrm{~h}$. Blood samples were collected in $10-\mathrm{mL}$ polystyrene vials containing $20 \mathrm{mg}$ of $\mathrm{Na}_{2}$ EDTA and kept in ice bath during sampling. Plasmas were harvested within $2 \mathrm{~h}$ after sampling and stored at $-20^{\circ} \mathrm{C}$ until analysis. Samples of vaginal discharge, obtained with a gloved hand, were observed by direct inspection and classified as normal clear discharge (VD-0); clear discharge with pus flecks (VD-1); mucopurulent, not fetid discharge (VD-2); or watery, purulent or brown colored, and fetid (VD-3; Williams et al., 2005). Calving history and milk yield were obtained from dairy records.

\section{Diagnostic Criteria}

Cows having a VD-1, VD-2, or VD-3 between 21 and 41 dpp were defined as having clinical endometritis. Cows having a VD-3 and a rectal temperature $<39.1^{\circ} \mathrm{C}$ on 5 to $7 \mathrm{dpp}$ were declared as having clinical metritis, and cows having a VD-3 and a rectal temperature $\geq 39.1^{\circ} \mathrm{C}$ on 5 to $7 \mathrm{dpp}$ were considered as having puerperal metritis.

\section{Laboratory Analysis}

Metabolites. Blood plasma samples were analyzed for NEFA, BHBA, and BUN using commercial kits [NEFA-HR(2) (Wako Chemicals USA Inc., Richmond, VA); Ranbut RB1007 (Randox Laboratories Ltd., Co. Antrim, UK); and Urea Color-2 (Wiener Laboratories SAIC, Rosario, Argentina), respectively]. Intraassay coefficients of variation were $5.7,6.3$, and $6.5 \%$ respectively. Interassay coefficients of variation were 7.1, 7.6, and $7.8 \%$ respectively. Metabolite concentrations were expressed in micromolar concentrations for NEFA and BHBA, and as milligrams per deciliter for BUN.

Metabolic Hormones. Hormones were measured by RIA as previously described (Lacau-Mengido et al., 2000; Díaz-Torga et al., 2001; Becú-Villalobos et al., 2007). Briefly, the IGF-1 RIA was performed, after acid-ethanol extraction, with the IGF-1 antibody [UB2495, Hormone Distribution Program of the National Institute of Diabetes \& Digestive \& Kidney Diseases (NIDDK), Bethesda, MD]. The minimum detectable concentration was $0.33 \mathrm{nM}$. Intra- and interassay coef- 
ficients of variation were 7.2 and $8.8 \%$, respectively. Insulin RIA was performed by using anti-bovine insulin antibody (Sigma, St. Louis, MO) and standard human insulin (Laboratorios Beta SA, Buenos Aires, Argentina). The minimum detectable concentration was 0.08 $\mathrm{ng} / \mathrm{mL}$, and intra- and interassay coefficients of variation were 6.8 and $8.9 \%$, respectively. Leptin RIA was performed by a double antibody method with ovinespecific antiserum (Delavaud et al., 2002) and recombinant bovine leptin (DS Laboratories Inc., Webster, TX; Becú-Villalobos et al., 2007). The minimum detectable concentration of leptin was $0.02 \mathrm{n} M$ and intra- and interassay coefficients of variation were 6.7 and $9.0 \%$, respectively. Metabolic hormone concentrations were reported in nanograms per milliliter.

\section{Statistical Analysis}

Data are shown as least squares means \pm standard error. Statistical significance was set at $P<0.05$ and a trend for significance was set at $P<0.10$. The cow was considered the experimental unit.

Binomial Variables. The logistic model for clinical risk factors for clinical endometritis included the fixed effects of parity ( 1 vs. $\geq 2$ ), calving (normal vs. abnormal), metritis (no vs. clinical vs. puerperal), and their second-order interaction. The model for metabolic risk factors included the effects of BCS, NEFA, BHBA, BUN, IGF-1, insulin, and leptin $14 \pm 3 \mathrm{~d}$ prepartum and $6 \mathrm{dpp}$. The model for reproductive outcomes was similar to that of clinical risk factors but included the fixed effect of clinical endometritis (yes vs. no). Models were analyzed with PROC GENMOD (SAS Institute, 2003) with binomial distributions and logit link functions. Modeling was performed using a manual backward elimination method with an exclusion criteria set at $P>0.2$.

Receiver Operator Characteristic. Receiver operator characteristic (ROC) analyses were used to determine critical thresholds for predicting clinical endometritis by using SigmaPlot 10.0 software (Systat Software Inc., 2006). The ROC curve analyzes sensitivity (Se) versus 1 - specificity (Sp). Sensitivity was the proportion of cows having clinical endometritis that was above a given threshold, and Sp was the proportion of animals not having clinical endometritis that was below a given threshold. Likelihood ratio positive $(\mathbf{L R}+)$ was the probability that a test result at or above the threshold would be more likely to come from a cow later diagnosed with endometritis (Greiner et al., 2000). The critical threshold was the point on the ROC curve that had the highest combined Se and Sp. Interpretation of critical threshold was based on the area under the curve. Swets (1988) suggested that the test is noninformative if the area is 0.5 , that it is accurate if the area is 0.5 to 0.7 , that it is very accurate if the area is 0.7 to 0.9 , that it is highly accurate if the area is 0.9 to 1.0 , and finally, that it is perfect if the area under the curve is 1 .

Multinomial Variables. Vaginal discharge was also analyzed as an ordinal variable repeatedly through the postpartum period (7-41 dpp). Thus, a repeated multinomial regression was run with PROC GENMOD (SAS Institute, 2003). A multinomial distribution (i.e., VD-0, VD-1, VD-2, and VD-3) and cumulative logit link function were used. The model included the fixed effect of time $(7,21,31$, and $41 \mathrm{dpp})$, parity ( 1 vs. $\geq 2$ ), calving (normal vs. abnormal), metritis (no vs. clinical vs. puerperal), and their second-order interactions.

Time to Event Variables. Calving-to-conception and calving-to-culling intervals by $300 \mathrm{dpp}$ were analyzed with PROC PHREG (SAS Institute, 2003). Cox proportional-hazards regression models included the same fixed effects as logistic models for reproductive performance. Modeling was performed using a manual backward elimination method with an exclusion criteria set at $P>0.2$. Time intervals (median $\pm 95 \% \mathrm{CI}$ ) for days open and survival function estimates were obtained from PROC LIFETEST (SAS Institute, 2003).

Continuous Variables. Milk, metabolites, and metabolic hormones were analyzed with PROC MIXED (SAS Institute, 2003) as repeated measures. The model included the random effect of the cow and the fixed effect of time (sampling day), together with the fixed effects previously described for logistic models assessing reproductive performance. The covariance structure having the smallest Akaike information criterion and Schwarz Bayesian criterion was used (Littell et al., 2002). A polynomial contrast was used to test the linear and quadratic effects of time on response variables, and another contrast was used to compare prepartum versus postpartum values.

\section{RESULTS}

Incidences of clinical endometritis during the postpartum period were $54.1 \%(164 / 303)$ at $21 \mathrm{dpp}, 33.0 \%$ (100/303) at $31 \mathrm{dpp}$, and $14 \%(45 / 303)$ at $41 \mathrm{dpp}$.

\section{Risk Factors}

Parity had no effect on the risk for clinical endometritis $(P=0.40)$. Cows with abnormal calving had higher risk for endometritis than normal calving herdmates [adjusted odds ratio $(\mathbf{A O R})=2.214,95 \% \mathrm{CI}=1.069$ to 4.586; Table 1]. Metritis had a trend for an effect on the risk for endometritis $(P=0.095)$; specifically, cows with puerperal metritis had greater odds of developing 
Table 1. Clinical and metabolic risk factors for clinical endometritis in Holstein dairy cows $(\mathrm{n}=303$ and 110, respectively)

\begin{tabular}{|c|c|c|c|c|c|}
\hline Item & \multicolumn{2}{|c|}{ Incidence } & \multicolumn{3}{|c|}{ Risk for clinical endometritis ${ }^{1}$} \\
\hline \multicolumn{6}{|l|}{ Clinical risk factor } \\
\hline Normal & 13.5 & $35 / 260$ & Referent & & \\
\hline Abnormal & 23.3 & $10 / 43$ & 2.214 & $1.069-4.586$ & \\
\hline Metritis & & & & & 0.095 \\
\hline Puerperal metritis ${ }^{3}$ & 22.2 & $20 / 90$ & 2.214 & $1.069-4.586$ & \\
\hline \multicolumn{6}{|l|}{ Metabolic risk factor ${ }^{4}$} \\
\hline Prepartum NEFA ${ }^{5}$ & - & 110 & 1.003 & $1.000-1.005$ & 0.045 \\
\hline Prepartum BUN ${ }^{6}$ & - & 110 & 0.853 & $0.689-1.058$ & 0.15 \\
\hline Postpartum $\mathrm{BHBA}^{7}$ & - & 110 & 1.001 & $0.999-1.003$ & 0.010 \\
\hline
\end{tabular}

${ }^{1}$ Clinical endometritis: cows having a vaginal discharge (VD) other than normal clear VD $41 \mathrm{~d}$ postpartum (dpp). AOR $=$ adjusted odds ratio.

${ }^{2}$ Clinical metritis: cows having a watery, purulent or brown-colored, and fetid VD, with rectal temperature $<39.1^{\circ} \mathrm{C} 5$ to $7 \mathrm{dpp}$.

${ }^{3}$ Puerperal metritis: cows having a watery, purulent or brown-colored, and fetid VD with rectal temperature $\geq 39.1^{\circ} \mathrm{C} 5$ to 7 dpp; second-order interactions had no effect on the clinical risk for clinical endometritis $(P>0.10)$.

${ }^{4}$ Risk factors with $P>0.2$ were excluded from the table.

${ }^{5}$ Nonesterified FA concentration $14 \pm 3 \mathrm{~d}$ prepartum.

${ }^{6}$ Blood urea nitrogen concentration $14 \pm 3 \mathrm{~d}$ prepartum.

${ }^{7} \beta$-Hydroxybutyrate concentration $6 \mathrm{dpp}$.

the disease than no-metritis herdmates $(\mathrm{AOR}=2.214$, $95 \% \mathrm{CI}=1.069$ to 4.586 ; Table 1 ). High prepartum NEFA increased the risk for endometritis $(\mathrm{AOR}=$ $1.003,95 \% \mathrm{CI}=1.000$ to 1.005$)$, whereas high prepartum $\mathrm{BUN}$ reduced it $(\mathrm{AOR}=0.853,95 \% \mathrm{CI}=0.689$ to 1.058; Table 1). Postpartum BHBA increased the risk for endometritis $(\mathrm{AOR}=1.001,95 \% \mathrm{CI}=0.999$ to 1.003; Table 1). The remaining indicators had no effect on the risk for the disease.

Prepartum NEFA had an ROC area of $0.75 \pm 0.09$ $(P=0.019)$ and a cut-off of $456.6 \mu M(\mathrm{Se}=0.693, \mathrm{Sp}$ $=0.875$, and $\mathrm{LR}+=5.419$; Figure 1$)$, whereas postpartum BHBA had an ROC area of $0.74 \pm 0.07(P=$ $0.042)$, a cut-off of $402.5 \mu M(\mathrm{Se}=0.579, \mathrm{Sp}=0.857$, and LR $+=4.051 ;$ Figure 2 ). The remaining predictors had ROC areas with $P>0.10$.

Cure Rate. Evolution of VD during the postpartum period is shown in Figure 3. The multinomial model showed that day had an effect on the risk for cure (that is, for having a VD-0, AOR $=1.073,95 \% \mathrm{CI}=1.063$ to $1.084, P<0.001$ ), and also that normal calving cows had higher odds for VD-0 than abnormal calving herdmates $(\mathrm{AOR}=2.557,95 \% \mathrm{CI}=1.737$ to $3.765, P<$ 0.001). The remaining predictors and their second-order interactions had no effect $(P>0.1)$. As the AOR for day seemed to be misleading (i.e., $7 \%$ increase in cure rate per 1-d increase during the postpartum period), the following equation: $\mathrm{AOR}=\beta \times \mathrm{p}_{\mathrm{i}}\left(1-\mathrm{p}_{\mathrm{i}}\right)$ was used to address this concern (Allison, 1999), where $\beta$ is the regression coefficient for day $[0.0705(95 \% \mathrm{CI}=0.0608$ to 0.0802$)$ ] and $\mathrm{p}_{\mathrm{i}}$ is the probability for VD-0 (0.8289).

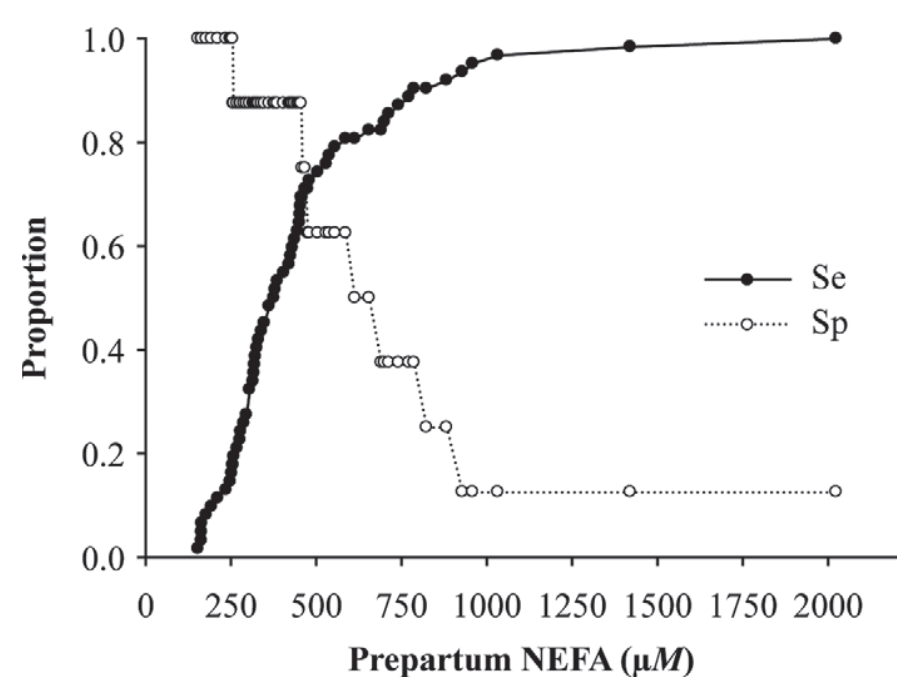

Figure 1. Receiver operator characteristic (ROC) analysis evaluation of NEFA 14 d postpartum (dpp) as a diagnostic test for clinical endometritis in dairy cows $(\mathrm{n}=110)$. Prepartum NEFA had an ROC area $(\mathrm{LSM} \pm \mathrm{SE})=0.75 \pm 0.09(P=0.019)$, a cut-off $=456.6$ $\mu M[$ sensitivity $(\mathrm{Se})=0.693$, specificity $(\mathrm{Sp})=0.875$, likelihood ratio positive $(\mathrm{LR}+)=5.419$, positive predicted values $(\mathrm{PV}+)=0.85$, and negative predicted values $(\mathrm{PV}-)=0.74]$. Vaginal discharge other than clear normal obtained with a gloved hand $41 \mathrm{dpp}$ was used as the gold standard. Sensitivity was the proportion of cows having endometritis that was above the threshold, and Sp was the proportion of animals not having endometritis that was below the threshold. Likelihood ratio positive was the probability that a test result at or above the threshold would be more likely to come from a cow later diagnosed with endometritis. The cut-off was the point on the ROC curve that had the highest combined Se and Sp. 


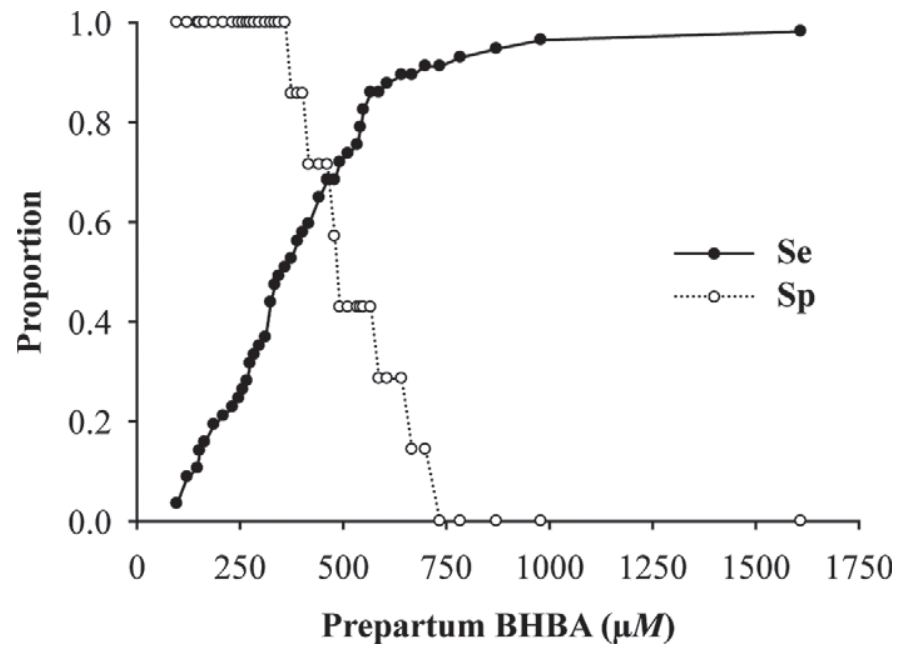

Figure 2. Receiver operator characteristic (ROC) analysis evaluation of BHBA $6 \mathrm{~d}$ postpartum (dpp) as a diagnostic test for clinical endometritis in dairy cows $(\mathrm{n}=110)$. Postpartum BHBA had an ROC area $(\mathrm{LSM} \pm \mathrm{SE})$ of $0.74 \pm 0.07(P=0.042)$, a cut-off $=402.5 \mu M$ $[$ sensitivity $(\mathrm{Se})=0.579$, specificity $(\mathrm{Sp})=0.857$, and likelihood ratio positive $(\mathrm{LR}+)=4.051$, positive predicted values $(\mathrm{PV}+)=0.80$, and negative predicted values $(\mathrm{PV}-)=0.67]$. Vaginal discharge other than clear normal obtained with a gloved hand $41 \mathrm{dpp}$ was used as the gold standard. Sensitivity was the proportion of cows having endometritis that was above the threshold, and Sp was the proportion of animals not having endometritis that was below the threshold. Likelihood ratio positive was the probability that a test result at or above the threshold would be more likely to come from a cow later diagnosed with endometritis. The cut-off was the point on the ROC curve that had the highest combined Se and Sp.

The corrected change in probability for VD-0 is 0.99 (0.86 to 1.14) per 1-d increase during the postpartum period (between 7 and $41 \mathrm{dpp}$ ).

\section{Effects on Reproduction}

Clinical endometritis decreased the risk for pregnancy by $100 \mathrm{dpp}(\mathrm{AOR}=0.098,95 \% \mathrm{CI}=0.022$ to $0.433, P=0.002)$, increased the risk for nonpregnancy by $200 \mathrm{dpp}(\mathrm{AOR}=2.868,95 \% \mathrm{CI}=1.276$ to $6.448, P$ $=0.011)$, reduced the hazard for pregnancy by $300 \mathrm{dpp}$ (hazard rate $=0.438,95 \% \mathrm{CI}=0.298$ to $0.644, P<$ 0.001), and extended the calving-to-conception interval by approximately $70 \mathrm{~d}$, from a median $(95 \% \mathrm{CI})$ of 115 (102 to 123) to 184 (153 to 233), log-rank test $=20.04$, degrees of freedom $=1, P<0.001$; Figure 4). Finally, clinical endometritis increased the risk for culling (AOR $=2.275,95 \% \mathrm{CI}=1.052$ to $4.919, P=0.034)$.

\section{Effects on Milk Yield}

Clinical endometritis had an effect on milk production $(25.67 \pm 0.41$ vs. $27.78 \pm 0.93 \mathrm{hg} / \mathrm{d}$, no vs. yes, respectively, $P=0.040$; Table 2$)$. Time by parity had an effect on milk yield $(P<0.001$; Table 2$)$, with mul-

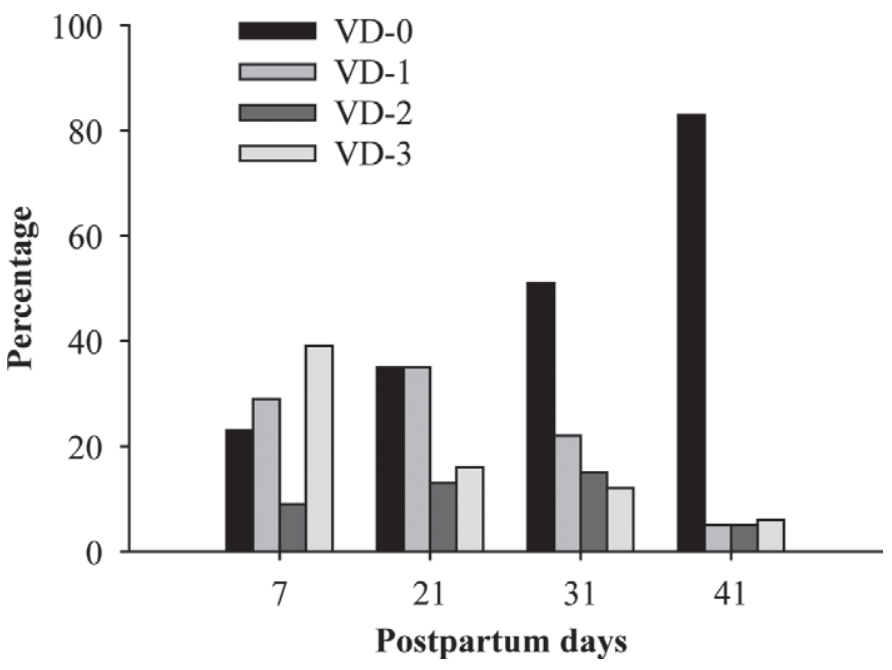

Figure 3. Evolution of vaginal discharge (VD) during the postpartum period in Holstein dairy cows $(\mathrm{n}=303)$. Vaginal discharge was classified as follows: normal clear (VD-0); clear with flecks of pus (VD1 ); mucopurulent, not fetid (VD-2); and watery, purulent or browncolored, and fetid vaginal discharge (VD-3). The probability for having normal VD increased $0.99 \%$ (0.86 to 1.14$)$ per 1 -d increase during the postpartum period (between 7 and $41 \mathrm{~d}$ ).

tiparous cows producing more milk $(\sim 5 \mathrm{~kg} / \mathrm{d})$ than primiparous herdmates from early to mid lactation (up to $165 \mathrm{~d}, P<0.01)$, and less milk $(\sim 4 \mathrm{~kg} / \mathrm{d})$ than primiparous cows at the end of lactation $(185 \mathrm{~d}, P<$ 0.01; figure not shown). Finally, time had a quadratic effect on milk $(P<0.001$; Table 2$)$.

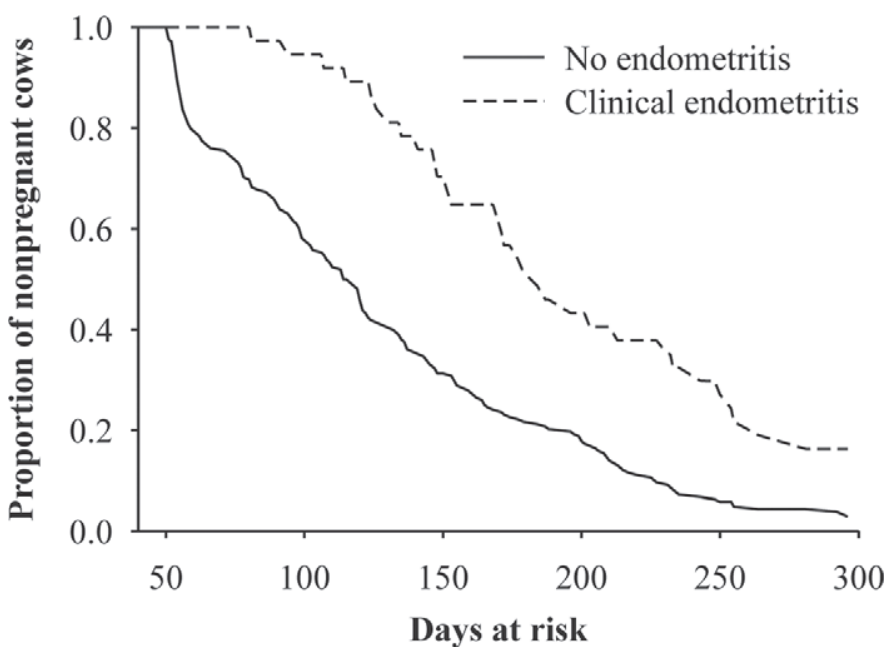

Figure 4. Survival function curves of calving-to-conception intervals by $300 \mathrm{~d}$ postpartum (dpp) in Holstein dairy cows $(\mathrm{n}=303)$. Clinical endometritis was defined as cows having vaginal discharge other than normal and clear $41 \mathrm{dpp}$. Cows with clinical endometritis had longer calving-to-conception intervals than normal herdmates [median (95\% CI): 184 (153 to 233) vs. 115 (102 to 123), respectively; log-rank test $=20.04, \mathrm{df}=1, P<0.001]$. 
Table 2. Mixed-model effects on milk yield and on indicators of metabolic status in Holstein dairy cows (milk and BCS, $\mathrm{n}=303 ;$ metabolites, $\mathrm{n}=110$; and hormones, $\mathrm{n}=50)^{1}$

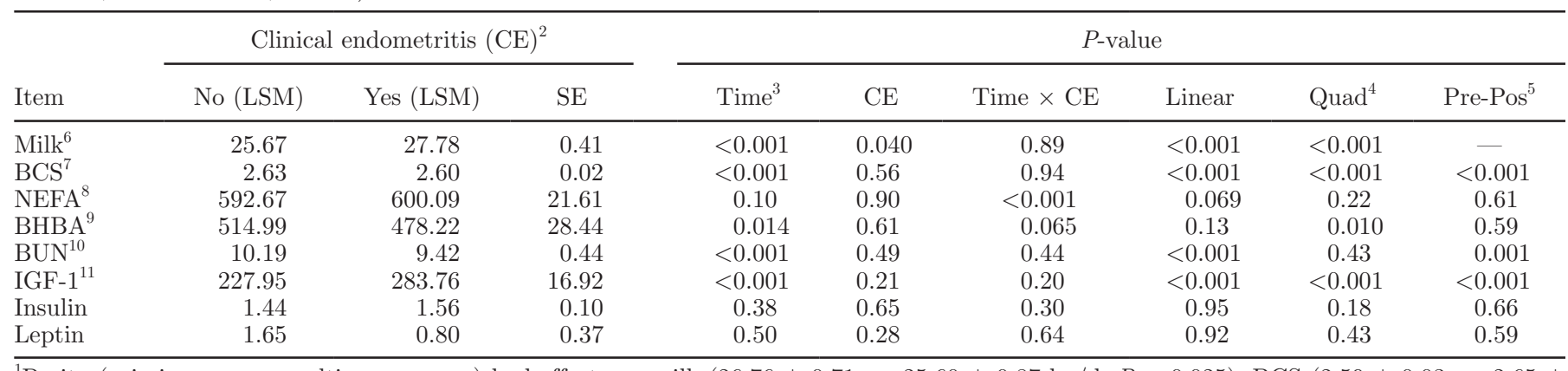

${ }^{1}$ Parity (primiparous vs. multiparous cows) had effects on milk $(26.76 \pm 0.71$ vs. $25.60 \pm 0.87 \mathrm{~kg} / \mathrm{d}, P=0.025)$, BCS (2.59 \pm 0.03 vs. $2.65 \pm$ $0.02, P=0.094)$, NEFA $(555.38 \pm 32.64$ vs. $630.89 \pm 22.09, P=0.058)$, BUN $(8.10 \pm 0.68$ vs. $12.05 \pm 0.46, P<0.001)$, and insulin $(1.62 \pm$ 0.12 vs. $1.28 \pm 0.15, P=0.074)$.

${ }^{2}$ Clinical endometritis: cows having vaginal discharge other than normal clear $41 \mathrm{~d}$ postpartum.

${ }^{3}$ Time: days related to parturition (d: $-14,6,21,31,41$, and 50).

${ }^{4}$ Quad: quadratic effects of time.

${ }^{5}$ Pre-Pos: prepartum versus postpartum values.

${ }^{6}$ Milk: milk yield $(\mathrm{kg} / \mathrm{d} ; \mathrm{n}=303)$.

${ }^{7}$ Body condition score: 5 -point scale $(\mathrm{n}=303)$.

${ }^{8}$ Nonesterified FA $(\mu M): \mathrm{n}=110$.

${ }^{9} \beta$-Hydroxybutyrate $(\mu M): \mathrm{n}=110$.

${ }^{10}$ Blood urea nitrogen $(\mathrm{mg} / \mathrm{dL}): \mathrm{n}=110$.

${ }^{11}$ Insulin-like growth factor $1(\mathrm{ng} / \mathrm{mL}): \mathrm{n}=50$.

\section{Effects on Metabolic Status}

Time had effects on BCS, BUN, and IGF-1 $(P<$ 0.001; Table 2). Parity (primiparous vs. multiparous cows) had effects on BCS ( $2.58 \pm 0.03$ vs. $2.65 \pm 0.03$, $P=0.029)$, NEFA (548.73 \pm 38.49 vs. $644.03 \pm 31.67$, $P=0.019), \operatorname{BUN}(7.75 \pm 0.76$ vs. $11.86 \pm 0.63, P$ $<0.001)$, and insulin $(1.62 \pm 0.12$ vs. $1.28 \pm 0.15, P$ $=0.067$; Table 2). Clinical endometritis had no effect on any of the studied indicators $(P>0.10$; Table 2). Time by clinical endometritis interaction had an effect on NEFA and BHBA concentrations $(P<0.001$ and 0.065 , respectively; Figure 5). The remaining interactions had no effect $(P>0.10)$. Time had linear effects on BUN $(P<0.001)$, and quadratic effects on BCS, BHBA, and IGF-1 $(P<0.001,0.010$, and $<0.001$, respectively; Table 2). Prepartum BCS, BUN, insulin and IGF-1 were higher than postpartum values $(P<$ 0.001, 0.004, 0.021, and $<0.001$, respectively; Table 2), whereas prepartum and postpartum NEFA and BHBA were similar $(P=0.62$ and 0.20 , respectively).

\section{DISCUSSION}

The objectives of this study were to assess the clinical and metabolic risk factors for clinical endometritis and its effects on reproductive performance, milk production, and metabolic status. The $14 \%$ incidence of endometritis is similar to that reported in previous works
(Ghanem et al., 2002; Le Blanc et al., 2002; Mejía and Lacau-Mengido, 2005; Gautam et al., 2010; Potter et al., 2010; Plöntzke et al., 2011).

\section{Risk Factors}

The risk for clinical endometritis increases in cows with abnormal calving and with metritis (especially puerperal metritis). Our data support previous reports that have found dystocia, retained placenta, and metritis as predisposing factors (Ghanem et al., 2002; Le Blanc et al., 2002; Dubuc et al., 2010a; Gautam et al., 2010; Potter et al., 2010). Calving problems are associated with human intervention, tissue lesions, and bacterial contamination, and all these factors predispose the cow to uterine infections such as metritis and endometritis (Sheldon et al., 2009). The risk also increases with high NEFA and BHBA concentrations. Therefore, cows with poor energy balance are at higher risk for clinical endometritis. In addition, indicators of energy balance such as prepartum NEFA $(\mathrm{Se}=0.69$, $\mathrm{Sp}=0.88$, and $\mathrm{LR}+=5.42)$ and postpartum BHBA $(\mathrm{Se}=0.58, \mathrm{Sp}=0.86$, and $\mathrm{LR}+=4.05)$ could be useful for the prediction of the disease. That supports previous studies showing that NEFA concentrations at wk -1 higher than $0.3 \mathrm{mM}$ (Kaufmann et al., 2010) or $0.5 \mathrm{mM}$ (Dubuc et al., 2010b) were associated with increased odds of clinical endometritis (odds ratio $=$ 9.08, Kaufmann et al., 2010; odds ratio $=1.31$, Dubuc 


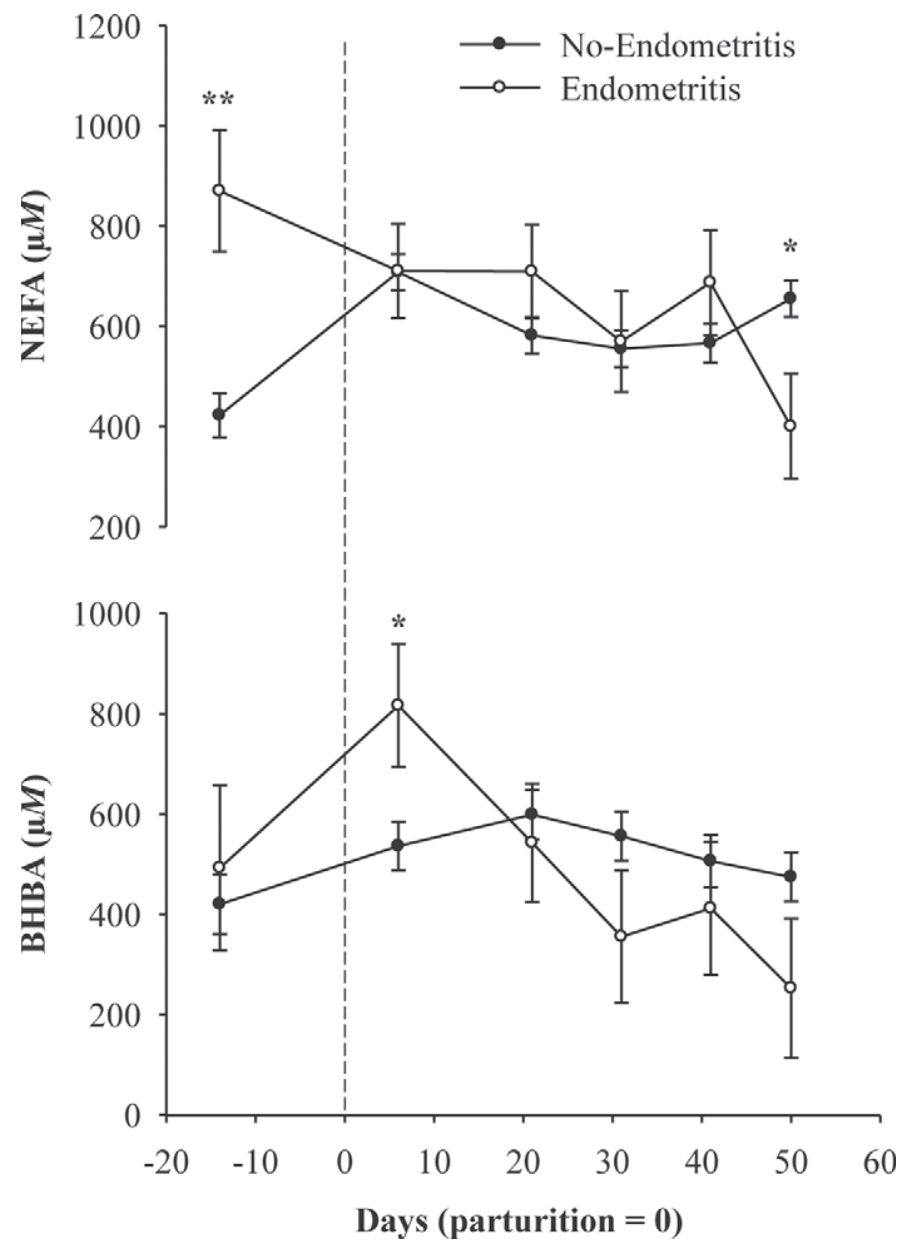

Figure 5. Mixed-model effects on NEFA and BHBA concentrations in Holstein dairy cows $(n=110)$ with or without clinical endometritis. Clinical endometritis was defined as cows having vaginal discharge other than normal and clear $41 \mathrm{~d}$ postpartum. A time by clinical endometritis effect was observed on both NEFA $(P<0.001)$ and BHBA $(P=0.065)$ concentrations. ${ }^{*} P<0.05,{ }^{*} * P<0.01$.

et al., 2010b). High prepartum NEFA and postpartum BHBA concentrations are indicative of negative energy balance, which may reflect a decrease in DMI (Bell, 1995; Horst et al., 1997). In turn, this negative energy balance may have a detrimental effect to neutrophil functions and, therefore, to uterine health (Hammon et al., 2006).

\section{Cure}

We also found that the likelihood for having a normal VD 41 dpp increased with time (1\% per dpp), and with normal calving, because they have higher odds than abnormal-calving cows $(\sim 2.5$ times $)$. The fact that cows having normal calving have a greater chance for VD-0 (i.e., cure) than herdmates having abnormal calving was expected for the reasons already mentioned (lower risk for tissue lesions and bacterial contamination). Spontaneous cure of clinical endometritis has recently been reported as common $(\sim 70 \%)$ during the postpartum period (Mejía and Lacau-Mengido, 2005; Gautam et al., 2010; Dubuc et al., 2011b; Plöntzke et al., 2011). In the present study, a multinomial logit with repeated measures was used, which accounted for the effect of postpartum time on the likelihood for having a normal VD. Thus, this is an unbiased measure of the relationship between postpartum time (dpp) and cure rate and, therefore, the first study that measures VD evolution (i.e., cure rate) in postpartum dairy cows accounting for the effect of dpp (cure: 1\% per dpp).

\section{Clinical Endometritis Effects}

Clinical endometritis reduces the risks for pregnancy by $100 \mathrm{dpp}$, and increases the risks for nonpregnancy by $200 \mathrm{dpp}$ and for culling. In addition, it reduces the hazard for pregnancy per day at risk and extends the calving-to-conception interval (by approximately 70 d). Therefore, this disease has various negative effects on reproductive performance. Our data supports the results from previous studies reporting detrimental effects of endometritis on reproduction (Fourichon et al., 2000; LeBlanc et al., 2002; Gautam et al., 2009, 2010; Gilbert et al., 2005; McDougall et al., 2007; Barlund et al., 2008; Runciman et al., 2008; Dubuc et al., 2010a, 2011b; Plöntzke et al., 2011). As we did not check cows for subclinical endometritis, our reference group of normal cows (no endometritis) may have included some animals having subclinical endometritis that may also have affected reproductive efficiency and, therefore, we could have underestimated the effect of clinical endometritis on reproductive performance. Many ways exist by which the negative effects of clinical endometritis could take place: first, through a delay in the return to cyclicity after parturition (Mateus et al., 2002; Sheldon et al., 2002); second, through the production of smaller corpora lutea with lower circulating concentrations of progesterone (Williams et al., 2007); third, through the clear disruption of the uterine environment (Bondurant, 1999; Sheldon and Dobson, 2004); and last, through an impairment of embryo development (Soto et al., 2003).

Cows having clinical endometritis produce more milk $(\sim 2 \mathrm{~kg} / \mathrm{d})$ than normal herdmates. That does not support previous reports showing no relationship between endometritis and milk production (Fourichon et al., 1999; Dubuc et al., 2011a). We do not have an explanation for this finding, but it could be due to the difference in production system, feeding regimen, and so on. Final findings were that clinical endometritis had no effect on metabolic status, as affected cows had similar levels of metabolites (BCS, NEFA, BHBA, and 
BUN), and metabolic hormones (insulin, IGF-1 and leptin) to normal herdmates. The lack of effect of clinical endometritis on metabolic status seems reasonable, as this factor is only restricted to the uterus and is not accompanied by systemic signs of illness (Sheldon et al., 2009), and is supportive of no detrimental effect on milk production. These results could be generalized to other farms under similar production systems.

\section{CONCLUSIONS}

Cows with abnormal calving, puerperal metritis, and in a deeper negative energy balance are at higher risk for clinical endometritis. Indicators of energy balance, such as prepartum NEFA and postpartum BHBA concentrations, could be useful for its prediction. The percentage of cows having normal VD increased with time postpartum (1\% per day) and was reduced in cows with calving problems. Clinical endometritis had detrimental effects on reproductive performance by extending calving-toconception intervals (by approximately $70 \mathrm{~d}$ ), reducing the risks for pregnancy by $100 \mathrm{dpp}$, increasing the risks for nonpregnancy by $200 \mathrm{dpp}$, and increasing the risk for cull. Affected cows produced more milk $(\sim 2 \mathrm{~kg} / \mathrm{d})$ than normal herdmates. Finally, clinical endometritis has no effect on metabolic status, as cows with the disease had similar BCS, and NEFA, BHBA, BUN, insulin, and leptin concentrations to normal herdmates.

\section{ACKNOWLEDGMENTS}

This study was financed by a Grant to RLS (V11/134, Proyecto de Incentivos, Univiversidad Nacional de La Plata). The authors thank the farm's owner and personnel for their support.

\section{REFERENCES}

Allison, P. D. 1999. Logistic Regression Using SAS: Theory and Application. SAS Institute Inc. Cary, NC.

Barlund, C. S., T. D. Carruthers, C. L. Waldner, and C. W. Palmer. 2008. A comparison of diagnostic techniques for postpartum endometritis in dairy cattle. Theriogenology 69:714-723.

Becú-Villalobos, D., I. García-Tornadú, G. Shroeder, E. E. Salado, G. Gagliostro, C. Delavaud, Y. Chilliard, and I. M. Lacau-Mengido. 2007. Effect of fat supplementation on leptin, insulin-like growth factor I, growth hormone, and insulin in cattle. Can. J. Vet. Res. $71: 218-225$.

Bell, A. W. 1995. Regulation of organic nutrient metabolism during transition from late pregnancy to early lactation. J. Anim. Sci. 73:2804-2819.

Bondurant, R. H. 1999. Inflammation in the bovine female reproductive tract. J. Anim. Sci. 77:101-110.

Burke, C. R., S. Meier, S. McDougall, C. Compton, M. Mitchell, and J. R. Roche. 2010. Relationships between endometritis and metabolic state during the transition period in pasture-grazed dairy cows. J. Dairy Sci. 93:5363-5373.

Delavaud, C., A. Ferlay, Y. Faulconnier, F. Bocquier, G. Kann, and Y. Chilliard. 2002. Plasma leptin concentration in adult cattle: Ef- fects of breed, adiposity, feeding level, and meal intake. J. Anim. Sci. 80:1317-1328.

Díaz-Torga, G. S., M. E. Mejía, A. González-Iglesias, N. Formía, D. Becú-Villalobos, and I. M. Lacau-Mengido. 2001. Metabolic cues for puberty onset in free grazing Holstein heifers naturally infected with nematodes. Theriogenology 56:111-122.

Dubuc, J., T. F. Duffield, K. E. Leslie, J. S. Walton, and S. J. LeBlanc. 2010a. Definitions and diagnosis of postpartum endometritis in dairy cows. J. Dairy Sci. 93:5225-5233.

Dubuc, J., T. F. Duffield, K. E. Leslie, J. S. Walton, and S. J. LeBlanc. 2010b. Risk factors for postpartum uterine diseases in dairy cows. J. Dairy Sci. 93:5764-5771.

Dubuc, J., T. F. Duffield, K. E. Leslie, J. S. Walton, and S. J. LeBlanc. 2011a. Effects of postpartum uterine diseases on milk production and culling in dairy cows. J. Dairy Sci. 94:1339-1346.

Dubuc, J., T. F. Duffield, K. E. Leslie, J. S. Walton, and S. J. LeBlanc. 2011b. Randomized clinical trial of antibiotic and prostaglandin treatments for uterine health and reproductive performance in dairy cows. J. Dairy Sci. 94:1325-1338.

Edmonson, A. J., I. J. Lean, L. D. Weaver, T. Farver, and G. Webster. 1989. A body condition scoring chart for Holstein dairy cows. J. Dairy Sci. 72:68-78.

Ferguson, J. D., D. T. Galligan, and N. Thomsen. 1994. Principal descriptors of body condition score in Holstein cows. J. Dairy Sci. 77:2695-2703.

Fourichon, C., H. Seegers, N. Bareille, and F. Beaudeau. 1999. Effects of disease on milk production in the dairy cow: A review. Prev. Vet. Med. 41:1-35.

Fourichon, C., H. Seegers, and X. Malher. 2000. Effect of disease on reproduction in the dairy cow: A meta-analysis. Theriogenology 53:1729-1759.

Gautam, G., T. Nakao, K. Koike, S. T. Long, M. Yusuf, R. M. S. B. K. Ranasinghe, and A. Hayashi. 2010. Spontaneous recovery or persistence of postpartum endometritis and risk factors for its persistence in Holstein cows. Theriogenology 73:168-179.

Gautam, G., T. Nakao, M. Yusuf, and K. Koike. 2009. Prevalence of endometritis during the postpartum period and its impact on subsequent reproductive performance in two Japanese dairy herds. Anim. Reprod. Sci. 116:175-187.

Ghanem, M., A. H. Shalaby, S. Sharawy, and N. Saleh. 2002. Factors leading to endometritis in dairy cows in Egypt with special reference to reproductive performance. J. Reprod. Dev. 48:371-375.

Gilbert, R. O., S. T. Shin, C. L. Guard, H. N. Erb, and M. Frajblat. 2005. Prevalence of endometritis and its effects on reproductive performance of dairy cows. Theriogenology 64:1879-1888.

Greiner, M., D. Pfeiffer, and R. D. Smith. 2000. Principles and practical application of the receiver-operating characteristic analysis for diagnostic tests. Prev. Vet. Med. 45:23-41.

Hammon, D. S., I. M. Evjen, T. R. Dhiman, J. P. Goff, and J. L. Walters. 2006. Neutrophil function and energy status in Holstein cows with uterine health disorders. Vet. Immunol. Immunopathol. 113:21-29.

Horst, R. L., J. P. Goff, T. A. Reinhardt, and D. R. Buxton. 1997. Strategies for preventing milk fever in dairy cattle. J. Dairy Sci. 80:1269-1280.

Kaufmann, T. B., M. Drillich, B.-A. Tenhagen, and W. Heuwieser. 2010. Correlations between periparturient serum concentrations of non-esterified fatty acids, beta-hydroxybutyric acid, bilirubin, and urea and the occurrence of clinical and subclinical postpartum bovine endometritis. BMC Vet. Res. 6:47-52.

Könyves, L., O. Szenci, V. Jurkovich, L. Tegzes, A. Tirián, N. Solymosi, G. Gyulay, and E. Brydl. 2009. Risk assessment of postpartum uterine disease and consequences of puerperal metritis for subsequent metabolic status, reproduction and milk yield in dairy cows. Acta Vet. Hung. 57:155-169.

Lacau-Mengido, I. M., M. E. Mejía, G. S. Díaz-Torga, A. Gonzalez Iglesias, N. Formía, C. Libertun, and D. Becú-Villalobos. 2000. Endocrine studies in ivermectin-treated heifers from birth to puberty. J. Anim. Sci. 78:817-824.

LeBlanc, S. J., T. F. Duffield, K. E. Leslie, K. G. Bateman, G. P. Keefe, J. S. Walton, and W. H. Johnson. 2002. Defining and diag- 
nosing postpartum clinical endometritis and its impact on reproductive performance in dairy cows. J. Dairy Sci. 85:2223-2236.

Littell, R. C., W. W. Stroup, and R. J. Freund. 2002. SAS for Linear Models. 4th ed. SAS Institute Inc., Cary, NC.

Mateus, L., L. L. da Costa, F. Bernardo, and J. R. Silva. 2002. Influence of puerperal uterine infection on uterine involution and postpartum ovarian activity in dairy cows. Reprod. Domest. Anim. $37: 31-35$.

McDougall, S., R. Macaulay, and C. Compton. 2007. Association between endometritis diagnosis using a novel intravaginal device and reproductive performance in dairy cattle. Anim. Reprod. Sci. 99:9-23.

Mejía, M. E., and I. M. Lacau-Mengido. 2005. Endometritis treatment with a $\mathrm{PGF}_{2 \alpha}$ analog does not improve reproductive performance in a large dairy herd in Argentina. Theriogenology 63:1266-1276.

NRC. 2001. Nutrient Requirements of Dairy Cattle. 7th rev. ed. Natl. Acad. Sci., Washington, DC.

Plöntzke, J., L. V. Madoz, R. L. De la Sota, W. Heuwieser, and M. Drillich. 2011. Prevalence of clinical endometritis and its impact on reproductive performance in grazing dairy cattle in Argentina. Reprod. Domest. Anim. 46:520-526.

Potter, T. J., J. Guitian, J. Fishwick, P. J. Gordon, and I. M. Sheldon. 2010. Risk factors for clinical endometritis in postpartum dairy cattle. Theriogenology 74:127-134.

Runciman, D. J., G. A. Anderson, J. Malmo, and G. M. Davis. 2008. Use of postpartum vaginoscopic (visual vaginal) examination of dairy cows for the diagnosis of endometritis and the association of endometritis with reduced reproductive performance. Aust. Vet. J. $86: 205-213$.
SAS Institute. 2003. SAS/STAT Software for Windows 9.1. SAS Inst. Inc., Cary, NC.

Sheldon, I. M., J. Cronin, L. Goetze, G. Donofrio, and H. J. Schuberth. 2009. Defining postpartum uterine disease and the mechanisms of infection and immunity in the female reproductive tract in cattle. Biol. Reprod. 81:1025-1032.

Sheldon, I. M., and H. Dobson. 2004. Postpartum uterine health in cattle. Anim. Reprod. Sci. 82-83:295-306.

Sheldon, I. M., D. E. Noakes, A. N. Rycroft, D. U. Pfeiffer, and H Dobson. 2002. Influence of uterine bacterial contamination after parturition on ovarian dominant follicle selection and follicle growth and function in cattle. Reproduction 123:837-845.

Soto, P., R. P. Natzke, and P. J. Hansen. 2003. Actions of tumor necrosis factor- $\alpha$ on oocyte maturation and embryonic development in cattle. Am. J. Reprod. Immunol. 50:380-388.

Swets, J. A. 1988. Measuring the accuracy of diagnostic systems. Science 240:1285-1293.

Systat Software Inc. 2006. SigmaPlot User's Guide. Version 10.0. Systat Software Inc., Chicago, IL.

Williams, E. J., D. P. Fischer, G. C. W. England, H. Dobson, D. U. Pfeiffer, and I. M. Sheldon. 2005. Clinical evaluation of postpartum vaginal mucus reflects uterine bacterial infection and the inflammatory response to endometritis in cattle. Theriogenology 63:102-117.

Williams, E. J., D. P. Fischer, D. E. Noakes, G. C. W. England, A Rycroft, H. Dobson, and I. M. Sheldon. 2007. The relationship between uterine pathogen growth density and ovarian function in the postpartum dairy cow. Theriogenology 68:549-559. 